\title{
SERTIFIKASI KAWASAN WISATA UNTUK PERLINDUNGAN BUDAYA DAN PELESTARIAN LINGKUNGAN HIDUP \\ (Kebutuhan Mendesak dalam Menyongsong \\ Tahun Kunjungan Wisata Nusantara)
}

\author{
Oleh: Ahmad Yani*)
}

\begin{abstract}
ABSTRAK
Sektor pariwisata pada umumnya dijadikan unggulan bagi Penerimaan Asli Daerah pemerintah daerah. Sektor ini diandalkan karena dapat memacu sektor lainnya, seperti peningkatan bisnis transportasi, hotel, restoran, hiburan, per-bankan, dan peningkatan permintaan terhadap hasil pertanian, peternakan, serta perikanan. Namun demikian, seiring dengan tingginya tingkat persaingan antar daerah, pengembangan objek dan kawasan wisata tidak mengenal istilah daya dukung dan daya lenting lingkungan hidup sehingga keadaannya menjadi rusak dan secara perlahan tidak lagi diminati wisatawan. Salah satu solusi untuk memantau dan meningkatkan motivasi dalam pengelola objek dan kawasan wisata, dipandang perlu adanya sistem sertifikasi kawasan wisata sebagai bentuk jaminan pelayanan kepada konsumen.
\end{abstract}

Kata kunci: sertifikasi, perlindungan, tahun kunjungan

*) Drs. Ahmad Yani, M.Si., adalah dosen Jurusan Pendidikan Geografi FPIPS UPI. 


\section{Pendahuluan}

Dalam era otonomi, sektor pariwisata pada umumnya dijadikan sektor unggulan bagi pemerintah daerah, karena sektor ini dapat memacu sektor lainnya, seperti peningkatan bisnis transportasi, hotel, restoran, hiburan, per-bank-an, dan peningkatan permintaan terhadap hasil pertanian, peternakan, serta perikanan. Artinya dengan memacu sektor pariwisata, pemerintah daerah akan mampu meraih keuntungan di bidang lainnya yang terkait. Oleh karena itu, setiap daerah berlomba untuk dapat menarik perhatian para wisatawan agar berkunjung ke daerahnya.

Namun demikian, seiring dengan tingginya tingkat persaingan antar daerah ternyata pengembangan objek dan kawasan wisata menjadi monoton. Setiap daerah menyajikan atraksi dan daya tarik yang sama padahal dari aspek potensi alam dan budaya mungkin saja berbeda. Oleh karena itu berkembanglah isu di tingkat nasional bahwa pemerintah pusat dianggap tidak adil dan pilih kasih. Pemerintah daerah mengapa bahwa pemerintah memacu objek dan kawasan tertentu sedangkan di tempat lain tidak. Sampai akhirnya, Dirjen Destinasi Pariwisata Departemen Kebudayaan dan Pariwisata mencanangkan program untuk meningkatkan pemerataan dan keseimbangan pengembangan destinasi pariwisata yang sesuai dengan potensi masing-masing daerah.

Tingginya persaingan untuk meraih sebanyak-banyaknya wisatawan, di sejumlah kawasan terkadang tidak mengenal istilah daya dukung dan daya lenting lingkungan dalam pengembangan kawasan wisata. Pemerintah daerah "tutup mata" terhadap keseimbangan lingkungan. Hasil akhirnya bukan kenyamanan bagi para wisatawan tetapi keluhan dari para wisatawan karena tidak nyaman dan tidak "alami" lagi.

Keresahan ini sebenarnya telah diungkapkan oleh sejumlah data. Perkembangan industri pariwisata mengalami puncak berkembangnya antara dekade 70-an sampai tahun 1990-an. Dekade ini dianggap sebagai masa perkembangan wisata massal hingga muncul suatu harapan bahwa pariwisata adalah industri yang dapat ditekuni sebagai industri jasa yang dapat mendatangkan keuntungan terbesar di dunia (Gartner, 1996). Namun kemudian, sepuluh tahun kemudian terlihat adanya berbagai dampak negatif dari kegiatan wisata terhadap komponen lingkungan sosial, budaya, biota dan berbagai ekosistem. Perdebatan isu tentang pariwisata yang menimbulkan berbagai dampak negatif tersebut secara perlahan telah menghilangkan citra baik pariwisata sebagai green industry menjadi industri yang merusak sosial, budaya dan lingkungan hidup.

Akhirnya setiap orang hampir sepakat bahwa industri ini perlu diselamatkan dengan melaksanakan suatu konsep pengembangan pariwisata yang dapat menciptakan pariwisata berkelanjutan. Wacana ini ingin menyampaikan gagasan bahwa kawasan wisata perlu dilindungi dengan suatu sistem sertifikasi tertentu. Gagasan intinya adalah bagaimana agar kawasan wisata tidak asal dibuka dan diselenggarakan oleh pemerintah daerah tetapi juga harus memiliki kepedulian terhadap pemeliharaan dan melestarikan lingkungan hidup. Harapannya, tidak hanya menjaga keberlanjutan objek wisata dalam arti fisik tetapi juga dalam arti sosial, budaya, dan ekonomi masyarakat sekitar. Jika suatu kawasan wisata diinvestigasi (melalui sertifikasi) ditemukan merusak lingkungan hidup dan sosial budaya masyarakat sekitar maka "wajib" bagi 
pemerintah pusat dan pemerintah daerah berani menutupnya atau mencabut izin usahanya.

Gagasan sertifikasi kawasan wisata sebenarnya sejalan dengan semakin tumbuhnya kesadaran wisatawan mancanegara terhadap lingkungan hidup, seperti isu pembangunan yang berwawasan lingkungan dan isu pemanasan global. Suatu saat, jika suatu kawasan wisata tidak ramah lingkungan maka bisa jadi tidak dikunjungi oleh para wisatawan. Mereka dilarang oleh kebijakan negara asalnya, untuk berkunjung ke suatu tempat (semacam travel warning).

Pertanyaan yang muncul adalah bagaimana prinsip dan konsep sertifikasi kawasan wisata yang dapat dikembangkan? Unsur-unsur apakah yang dapat dijadikan indikator penilaian dalam model sertifikasi kawasan wisata?, dan bagaimana keunggulan dan kelemahan sistem sertifikasi kawasan wisata untuk dapat diterapkan?

\section{Konsep Wisata Berkelanjutan}

Dalam perspektif ekonomi, pembangunan berkelanjutan adalah proses produksi yang tidak mengurangi kapasitasnya di masa mendatang. Namun kemudian, pengertian ini menjadi semakin lengkap karena tidak hanya aspek produksi yang diperhatikan tetapi juga mempertimbangkan aspek lainnya. Pembangunan berkelanjutan selalu mempertimbangkan kebutuhan manusia di masa kini dan masa mendatang. Pembangunan berkelanjutan dilaksanakan karena didorong oleh suatu kenyataan bahwa kebutuhan hidup generasi rnendatang semakin banyak dan beranekaragam.

Pengertian pembangunan berkelanjutan diawali dari pemikiran Brundtland tentang kriteria terhadap pembangunan yang terjadi saat itu, dengan judulnya yang sangat terkenal yaitu Our Common Future pada tahun 1987. Di Indonesia, kesepakatan pembangunan berkelanjutan ini telah melahirkan berbagai kebijakan pembangunan di berbagai bidang termasuk di dalam bidang pariwisata.

Pariwisata semula diduga tidak menimbulkan kerusakan lingkungan karena pariwisata adalah green industry ternyata akhir-akhir ini telah juga memberi dampak negatif terhadap sumberdaya alam dan lingkungan. Hal ini tidak hanya terjadi di Indonesia, tetapi terjadi pula di negara-negara destinasi utama pariwisata dunia. Kondisi ini kemudian ikut mendorong terjadinya pergeseran kepariwisataan dari pariwisata lama ke pariwisata baru, yang mempergunakan prinsip konervasi lingkungan dalam pemanfaatan seluruh sumberdaya untuk pariwisata.

Pariwisata baru yang muncul telah merubah wajah kepariwisataan, tidak hanya dari aspek pasar tetapi juga aspek produk. Pembangunan pariwisata berkelanjutan di Indonesia harus dilaksanakan dalam kerangka paradigma baru dalam pembangunan dan sekaligus sebagai upaya repositioning. Sebab bila tidak dilaksanakan, kepariwisataan nasional akan selalu kalah kompetisi dengan negara-negara tetangga. Di samping itu, bidang pariwisata akan menyebabkan terjadinya pemanfaatan sumberdaya alam dan lingkungan yang merusak dan tidak terjamin keberlanjutannya.

Pembangunan pariwisata berkelanjutan sebagai suatu kebijakan baru mulai diperhatikan melalui perumusan visi baru, strategi dan program-program baru dalam pembangunan di bidang pariwisata. Program ini seharusnya sudah tercermin dalam program nasional, regional dan lokal. Apalagi saat ini, dalam era 
reformasi, otonomi dan demokrasi perlu tercermin pada perencanaan dan sekaligus dalam pelaksanaan pembangunan. Perencanaan pembangunan pariwisata selain harus menjamin keberlanjutannya juga harus terkait dengan aspek pendidikan dan partisipasi masyarakat lokal. Jaminan keberlanjutan ini tidak hanya sustainable dari aspek lingkungan tetapi juga sosial, budaya dan ekonomi. Paradigma baru dalam pembangunan diakomodir dalam pembangunan pariwisata dengan mengedepankan keterbukaan, pemberdayaan masyarakat dan mengembangkan ekonomi kerakyatan disamping pelestarian lingkungan. Sementara itu dengan menguatnya peran daerah dan masyarakat lokal serta tetap mengupayakan konservasi lingkungan, pariwisata nasional akan memenangkan persaingan global.

Pembangunan pariwisata yang berkelanjutan hampir sama dengan kajian kelayakan lingkungan yang secara nasional telah disepakati yaitu Analisis Mengenai Dampak Lingkungan AMDAL). Pada setiap kawasan yang akan dikembangkan untuk pariwisata perlu disusun AMDAL, termasuk kawasan pelestarian dan pemanfaatan. Di dalam AMDAL bidang pariwisata perlu ditetapkan secara nyata terhadap pengembangan produk pariwisata dan aktivitas wisatanya. Menurut Fandeli (2005), pengembangan produk dalam suatu kawasan pariwisata (dan dipertimbangkan dalam studi AMDAL, pen) terdiri atas:

(1) Atraksi-atraksi yang dikembangkan dipilih yang memiliki nilai jual tinggi baik atraksi alam, heritage, budaya dan buatan.

(2) Infrastruktur (fasilitas, utilitas). Pembangunan fasilitas dan utilitas dibangun sesuai dengan budaya dan tradisi lokal serta terpadu dengan lingkungannya.

(3) Kelembagaan. Kelembagaan lokal diperkuat dan diberikan peranan masyarakat yang lebih besar.

(4) SDM (Sumberdaya Manusia), pariwisata pada dasarnya menjual penjualan maka kualitas SDM sangat menentukan keberhasilan sesuai dengan sasarannva.

(5) Aspek ekonomi. Ekonomi yang dikembangkan adalah ekonomi kerakyatan. Penghasilan kawasan dimaksud untuk dapat mempertahankan atau mengkonservasi kawasan dan meningkatkan kesejahteraan masyarakat lokal.

(6) Lingkungan. Kawasan dikaji kelayakannya utamanya dampak positif dan dampak negatif yang akan muncul. Analisis Mengenai Danpak Lingkungan merupakan instrumen untuk mengkaji dampak lingkungan dan bagaimana untuk mengkaji dampak dan bagaimana menanganinya.

Apabila keenam butir dapat dilaksanakan dalam suatu kawasan pariwisata maka pembangunan pariwisata berkelanjutan di dalam kawasan dapat terwujud, Indikator berikut dapat dipergunakan sebagai bahan untuk monitoring dan evaluasi (Fandeli, 2005): 
TABEL1 INDIKATOR UNTUK MONITORING DAN EVALUASI PEMBANGUNAN PARIWISATA BERKELANJUTAN

\begin{tabular}{|c|c|c|}
\hline No & Indikator & Ukuran Spesifik \\
\hline 1 & Perlindungan lokasi & $\begin{array}{l}\text { Daya dukung, tekanan terhadap areal dan } \\
\text { kemenarikan }\end{array}$ \\
\hline 2 & Tekanan & $\begin{array}{l}\text { Jumlah wisatawan yang berkunjung } \\
\text { pertahun/bulan/masa puncak }\end{array}$ \\
\hline 3 & Intensitas pemanfaatan & $\begin{array}{l}\text { Intensitas pemanfaatan pada waktu puncak } \\
\text { (wisatawan/ha) }\end{array}$ \\
\hline 4 & Dampak sosial & $\begin{array}{l}\text { Rasio antara wisatawan dan penduduk lokal } \\
\text { (pada waktu puncak/rata-rata) }\end{array}$ \\
\hline 5 & $\begin{array}{l}\text { Pengawasan } \\
\text { pembangunan }\end{array}$ & $\begin{array}{l}\text { Adanya prosedur secara formal terhadap } \\
\text { pembangunan di lokasi dan kepadatan } \\
\text { pemanfaatan }\end{array}$ \\
\hline 6 & Pengelolaan limbah & $\begin{array}{l}\text { Persentase limbah terhadap kemampuan } \\
\text { pengolahan. Demikian pula terhadap rasio } \\
\text { kebutuhan dan suplai air bersih }\end{array}$ \\
\hline 7 & Proses perencanaan & $\begin{array}{l}\text { Mempertimbangkan perencanaan regional } \\
\text { termasuk perencanaan wisata (regional) }\end{array}$ \\
\hline 8 & Ekosistem kritis & $\begin{array}{l}\text { Jumlah spesies yang masih jarang dan } \\
\text { dilindungi }\end{array}$ \\
\hline 9 & Kepuasan pengunjung & $\begin{array}{l}\text { Tingkat kepuasan pengunjung berdasarkan } \\
\text { pada kuesiner. }\end{array}$ \\
\hline 10 & $\begin{array}{l}\text { Kepuasan penduduk } \\
\text { lokal }\end{array}$ & $\begin{array}{l}\text { Tingkat kepuasan penduduk lokal bersadarkan } \\
\text { kuesiner }\end{array}$ \\
\hline 11 & $\begin{array}{l}\text { Kontribusi pariwisata } \\
\text { terhadap ekonomi lokal }\end{array}$ & $\begin{array}{l}\text { Proporsi antara pendapatan total dengan dari } \\
\text { pariwisata }\end{array}$ \\
\hline
\end{tabular}

Sumber: WTO (1996) dan Fandeli (2005)

Pada prinsipnya pembangunan pariwisata berkelanjutan dapat dicapai bila dipenuhi kriteria berikut:

(1) Keberlanjutan dengan kriteria kelestarian lingkungan dan sesuai dengan daya dukungnya. Ada beberapa pendekatan cara perhitungan daya dukung yang semuanya dapat dipergunakan sebagai pedoman menetapkan jumlah wisatawan agar tidak terjadi kerusakan pada kawasan. Ada tiga macam cara untuk memperhitungkan daya dukung yaitu daya dukung fisik, daya dukung realitas, dan daya dukung efektif atau daya dukung yang direkomendasi.

(2) Keberlanjutan Sosial. Pada beberapa daerah tujuan wisata terlihat adanya ketidakberlanjutan pariwisata dari aspek sosial ini. Ketidakberlanjutan pariwisata disebabkan oleh karena masyarakat terpengaruh dan terbawa oleh nilai-nilai sosial budaya wisatawan. Sistem sosial setempat yang secara tradisional mampu menciptakan image tertentu harus dipertahankan. Di dalam pariwisata, image yang bagus merupakan satu faktor yang menentukan keberhasilan. 
(3) Keberlanjutan Budaya. Budaya masyarakat akan menjadi daya tarik yang sangat kuat bagi wisatawan. Budaya perlu dipertahankan karena seni yang ada di masyarakat dalam kurun waktu panjang seringkali secara perlahan dapat mengalami perubahan. Perubahan ini merupakan dampak negatip dari kegiatan pariwisata. Jika budaya telah hilang maka hilang pula daya tarik budaya di daerah bersangkutan.

(4) Keberlanjutan dalam ekonomi. Keberlanjutan ekonomi dalam pariwisata sering dipergunakan sebagai kriteria untuk rneningkatkan pendapatan masyarakat lokal, kawasan pariwisata dan pemerintah. Pengertian tersebut tidak seluruhnya benar. Ada satu aspek yang lebih penting adalah bahwa nilai ekonomi yang diperoleh dari pengembangan pariwisata, yang dapat menutup seluruh nilai untuk melakukan penanganan dampak negatip lingkungan, sosial dan budava. Valuasi terhadap kerusakan atraksi wisata atau perubahan sosial budaya masyarakat harus dilakukan terhadap nilai ekonomi yang diperoleh.

\section{Konsep dan Perkembangan Sistem Sertifikasi}

Kesadaran konsumen dan produsen terhadap mutu dan lingkungan hidup, akhir-akhir ini semakin menaik. Kesadaran terhadap mutu dan keadaan lingkungan hidup tersebut terkait dengan produksi, penggunaan, dan pembuangan bahanbahan.

Produsen dapat meningkatkan mutu barangnya dengan memakai bahan baku yang bermutu tinggi dan pengolahan yang cermat. Dengan pemilihan bahan baku dan pengolahan yang ramah lingkungan serta penghematan energi, maka produk tersebut menjadi lebih ramah lingkungan. Produk yang ramah lingkungan selain menggunakan bahan baku setempat (yang terbarukan atau yang dilestarikan), tetapi juga tidak melepaskan zat-zat berbahaya atau beracun apapun ke lingkungan hidup, dan menghemat energi yang tidak terbarukan selama proses produksi, pemakaian, serta pembuangan. Dengan demikian, lingkungan hidup terlindungi dan kesehatan masyarakat dilestarikan.

Dalam sistem produk ramah lingkungan, peranan penting lainnya adalah para konsumen. Pembeli hendaknya juga mengembangkan kesadaran terhadap barang yang dipilih, bukan hanya harga yang menentukan keputusan pada waktu membeli barang. Pilihan tersebut akan mempengaruhi pasar. Jika, misalnya, suatu merek yang produknya tidak sesuai standar keamanan dan tidak ada lagi orang yang membelinya, maka produsen secara tidak langsung dipaksa untuk memperbaiki produknya. Hal ini berarti bahwa kekuatan konsumen cukup tinggi. Jika setiap konsumen berpendapat bahwa ia sendiri tidak dapat mengubah perilaku pasar yang memang sulit dipengaruhi, pasti tidak akan mengubah sikap produsen. Akhirnya, konsumen bertanggung jawab terhadap diri sendiri, hingkungan hidupnya, serta generasi yang akan datang.

Dalam industri pariwisata, isu mutu sebagaimana di jelaskan di atas sangat relatif dan kurang populer karena menyangkut kepuasan pelayanan dari para produsen yang dirasakan oleh konsumen. Isu yang menguat dalam industri pariwisata adalah justru pada perlindungan terhadap lingkungan hidup, yang kemudian kita kenal dengan istilah ekowisata. 
Lahirnya konsep ekowisata sebenarnya tidak terlepas dari isu ekolabel yang dipakai dalam produksi barang-barang. Ekolabel merupakan kelanjutan dari label-label lainnya seperti label mutu (seperti ISO 9000), Standar Industri Nasional, dan lain-lain. Ekolabel merupakan label ekologis yang melekat pada brosur-brosur produksi barang.

Di dunia Barat, konsumen untuk mendapatkan informasi singkat melalui label pada bahan yang dibeli adalah hal yang sudah biasa. Pada pandangan pertama, tampaknya, produk tersebut cenderung lebih mahal daripada produk yang tidak berlabel. Namun, banyak konsumen justru mencari, meminta, dan memilih produk yang berlabel. Oleh karena itu, di masa kini bermacam label baru dan produk yang berlabel dipasarkan. Konsumen umumnya setuju untuk membayar bahan lebih mahal asalkan ada label yang dapat dipercaya.

Suatu label pada dasarnya memberi keterangan lebih banyak tentang ciri khas suatu produk daripada produk yang tidak berlabel. Dengan informasi lebih lengkap tentang syarat pembuatan produk, bahan baku, atau daerah pembuatan, si pembeli akan menerima pengetahuan yang lebih lengkap mengenai bahan tersebut, dan mutu produk bahan tensebut biasanya lebih tinggi. Suatu label memberi bantuan dalam pemilihan produk dan jasa yang makin lama makin banyak karena pasar global yang terbuka.

Label dapat digolongkan atas label yang terfokus pada lingkungan hidup, pada persyaratan sosial dan kesehatan, pada wilayah pembuatan, pada mutu produk, dan pada komitmen keyakinan agamanya. Produk yang memiliki label ekologis akan menginformasikan kepada pembeli tentang bahan dan pencemaran lingkungan hidup. Keterangan label ekolongis tersebut mencakup peredaran bahan (life cycle assessment = LCA), mengandung usaha perolehan bahan haku, cara pembuatan, pendistribusian, penggunaan, serta pembuangan. Dengan demikian, kriteria untuk tahapan riwayat hidup masing-masing bahan juga mencakup terjadinya sampah, pencemaran air, tanah, udara, emisi kebisingan, kebutuhan energi. kebutuhan sumber alam, serta dampaknya terhadap ekosistem.

Gambaran tentang produk yang dipromosikan menjadi lebih tepat terutama berhubungan dengan pencemaran lingkungan hidup yang lebih rendah. Sebagai contoh ditemukan istilah seperti 'bebas fluorhidrokarbon', 'kebisingan minim' atau untuk bahan elektronik 'kebutuhan listrik dalam keadaan stand-by rendah'. Label ekologis berhubungan dengan pariwisata dan jasa biasanya memusatkan pada mutu dan ramah lingkungannya. Kawasan wisata yang memiliki label ekologis dikenal dengan ekowisata.

Produk yang memiliki label biologis juga merupakan label lingkungan hidup yang penting. Produk tersebut dihasilkan oleh bidang pertanian biologis/organik. Di Uni Eropa, tuntutan minimal suatu produk diatur dalam undang-undang yang harus dipenuhi jika suatu produk akan dipasarkan dengan label biologis dan perusahaan apa pun. Tuntutan tersebut mencakup kriteria tentang kesuburan dan aktivitas biologi tanah atau penggunaan pestisida dan pupuk.

Produk dengan label energi juga merupakan label lingkungan hidup. Label energi diarahkan terutama pada kebutuhan energi alat elektronik. Penggunaan label seperti GEA (Group for Efficient Appliances) berasal dan Eropa. Karena memiliki komponen ekonomis yang cukup kuat, label energi menunjukkan kemampuan menghemat biaya selama produk dipakai. Label energi yang lain mengacu pada sistem pembangkit listrik seperti energi surya, angin, atau air. 
Label yang persyaratannya berkaitan dengan kegiatan sosial dan kesehatan biasanya dapat memperbaiki persyaratan keadaan para buruh yang terkait dalam pengolahan bahan. Biasanya, persyaratan tersebut berupa persyaratan keselamatan kerja dan atau upah yang lebih baik daripada produsen lain. Kemungkinan lain adalah harga jual produk sebagian akan dipakai untuk membiayai program sosial, pendidikan, dan kesehatan. Label sosial tersebut mengacu pada hak dasar sosial yang ditetapkan.

Label yang mengutamakan mutu produk atau jasa mengandung kriteria keamanan. Pada label pemerintah, pemerintah bertanggung jawab untuk memberi dan mengawasi label tersebut, menetapkan kriteria, dan mengkoordinasinya dengan pihak terkait. Penggunaan label bersifat sukarela, tetapi jika produsen memutuskan memakal label, maka tuntutan yang ditentukan oleh pemerintah harus dipenuhi. Pada label swasta, institusi swasta bertanggung jawab untuk memberi dan mengawasi label tersebut, mengkoordinasi kriteria yang harus dipenuhi oleh produsen.

Perkembangan labeling produk barang terus berkembang ke arah yang lebih "idealis" yaitu didasarkan pada proses produksi yang bermoral keagamaan, yaitu misalnya label "produk muslim". Konsep labeling produk muslim berkembang di Malaysia. Implementasinya adalah seluruh bahan mentah dan bahan baku barang dari unsur yang halal. Proses perjanjian dengan karyawan sesuai dengan syariat Islam, waktu produksi diatur sedemikian rupa agar tidak menggangu kewajiban menjalankan agama (sembahyang dan ritual lainnya), sampai pada distribusi barang dilakukan dengan perjanjian yang islami.

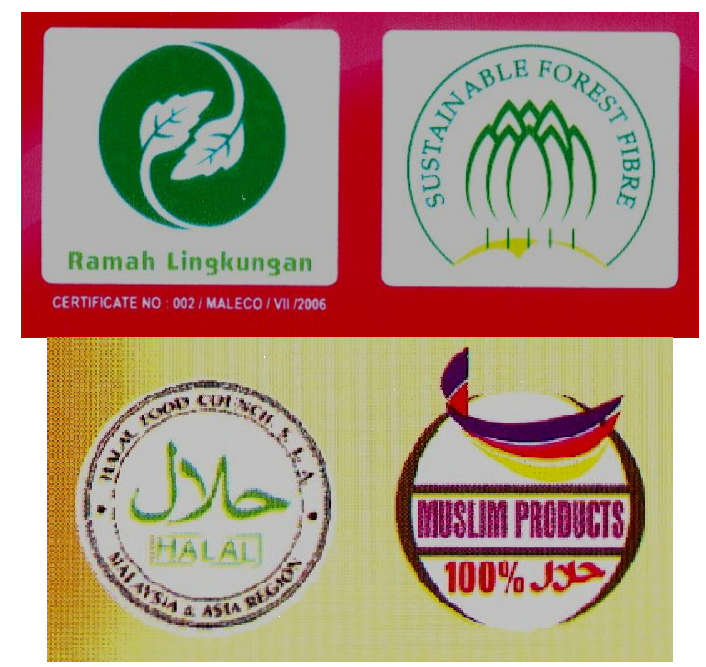

Gambar: labeling produk ramah lingkungan, label halal, dan label produk muslim

Apakah kawasan pariwisata dapat diberikan ekolabel? Sebenarnya hampir semua produk cocok untuk dilengkapi dengan ekolabel. Label dapat dilihat sebagai perkembangan brosur produk atau jasa. Suatu ekolabel memberi keterangan 
tentang pelestarian lingkungan hidup dan pembangunan berkelanjutan sehingga semua produk yang ramah lingkungan dengan perhatian pada seluruh rantai bahan akan dapat dilabelkan. Dengan memanfaatkan bahan baku yang dapat ditumbuhkan kembali, yang memakai tenaga listrik terbarukan pada pembuatan produk, dan mengelola gas buangan, limbah, dan sampah secara ramah lingkungan, sebuah produk baru menjadi layak dilabelkan.

Bukan hanya produk yang layak untuk dilabelkan, tetapi juga bidang jasa dapat diberi ekolabel, misalnya pariwisata ekologis, di mana para pelanggan menginap di ekohotel yang ramah lingkungan, dan sebagainya. Sebagai contoh akan dibicarakan label FSC, yaitu Forest Stewardship Council yang mengusahakan manajemen hutan ramah lingkungan di seluruh dunia dan memberi keuntungan kepada masyarakat lokal. Prinsip label FSC (principles of forest stewardship) ingin menghindari penebangan liar dan perdagangan kayu liar, kayu yang gennya dimanipulasi, kayu dan daerah perang dan pelanggaran HAM, serta kayu yang berasal dan hutan yang diubah rnenjadi kebun budidaya seperti monokultur kelapa sawit, dan sebagainya.

Di bidang pangan ada bermacam kemungkinan untuk mengurangi dampak negatif terhadap lingkungan alam oleh pengolahan bahan pangan yang memberi peluang untuk mendapatkan label ekologis. Label biologis berarti bahwa petani tidak memakai pestisida atau pupuk kimia, tetapi juga ada label yang menuntut agar lahan ditanami dengan beraneka jenis tumbuhan untuk menghindari efek monokultur. Di bidang peternakan, ekolabel melarang pemakaian obat ternak seperti antibiotika, psikofarmaka, atau hormon penggemuk. Tuntutan lain berupa ukuran kandang minimal per ekor ternak yang harus disediakan.

\section{Sertifikasi Kawasan Wisata}

Undang-undang kepariwisataan Tahun 2002 pada Bab VII pasal 36 menekankan bahwa pengembangan kawasan dan objek wisata agar didasarkan pada pertimbangan aspek agama, sosial budaya, kelestarian dan mutu lingkungan dan mengikutsertakan masyarakat dalam mitra kepemilikan. Dengan mengacu pada ketentuan tersebut, kawasan wisata sudah dapat dipastikan dapat diberi sertifikasi. Logikanya adalah kawasan wisata dapat dikatakan baik dan atau bermutu adalah jika kawasan dan objek wisata yang dibangun telah memperhatikan aspek-aspek sesuai undang-undang.

Menurut kajian Darsiharjo, dkk (2007) ada dua aspek yang dapat dikembangkan dalam sistem sertifikasi kawasan wisata yaitu potensi alam dan bagaimana perlakuan pengelola dalam menangani potensi alam tersebut. Dengan usulan konsep tersebut, diajukan pula dua jenis sasaran sertifikasi yaitu objek material dan objek formal.

Objek material penilaian sertifikasi adalah kawasan wisata. Kawasan wisata sebagai suatu luas wilayah tertentu yang dibangun atau disediakan untuk memenuhi kebutuhan pariwisata, termasuk di dalamnya objek dan daya tarik wisata adalah suatu objek penilaian yang merupakan hasil dari serangkaian kegiatan manusia. Keberadaan kualitas suatu kawasan wisata adalah akumulasi dari kegiatan para pengelola dalam usahanya melayani pelanggan. Sebagai objek material, kawasan wisata dapat dilihat dari berbagai sudut penilaian sesuai kepentingan di suatu waktu dan tempat. Artinya, di masa depan orang dapat juga 
melakukan sertifikasi terhadap sejumlah kawasan wisata dari sudut nilai ekolabel, nilai kualitas, nilai pelayanan, dan lain-lain. Perbedaan sudut pandang inilah yang kemudian melahirkan istilah objek formal.

Objek formal penilaian dalam sistem sertifikasi yang dikembangkan ini akan difokuskan kepada kinerja para pengelola dalam melahirkan produk-produk pariwisata, pemberian pelayanan jasa pariwisata, pemasaran, kegiatan konservasi, tata ruang, dan pelibatan unsur masyarakat. Adapun yang dimasud dengan para pengelola adalah pihak pemerintah, pihak swasta, investor, masyarakat, dan atau stakeholder lainnya.

Aspek produksi pariwisata adalah suatu kegiatan yang melahirkan produk wisata seperti memunculkan alternatif atraksi, rekreasi, penyelenggaraan festival, konvensi, event, studi, wisata olah raga, dan lain-lain. Produk yang dihasilkan baik yang bersumber dari potensi daya tarik wisata alam maupun potensi daya tarik budaya. Untuk penilaian sertifikasi, kita dapat mengukur kinerja pengelola dari tingkat produktivitasnya.

Aspek pelayanan adalah usaha pengelola untuk memuaskan pelanggan atau wisatawan. Pelayanan lebih menekankan pada aspek sumberdaya manusia dengan demikian penilaian perlu diambil dari tanggapan para pengunjung secara subjektif, seperti keseragaman, penampilan, kesopanan dalam kecekatan dalam menerima telepon, menangani complaint, peduli terhadap tamu, dan lain-lain. Aspek pelayanan yang lebih luas termasuk di dalamnya adalah penyediaan berbagai fasilitas pokok dan pendukung. Lingkup fasilitas pariwisata yang dinilai adalah fasilitas aksesibilitas, hospitality, dan amenitas.

Pemasaran pariwisata adalah seluruh kegiatan untuk mempertemukan permintaan (demand) dan penawaran (supply), sehingga pembeli mendapat kepuasan dan penjual mendapat keuntungan maksimal dengan resiko seminimal mungkin. Kegiatan pemasaran pariwisata dapat dilihat dari alat promosi yang digunakan, lingkup wilayah promosi, sales support yang digunakan (brosur, prospectus, direct-mail, folder, leaflet, booklet, guide-book, display material, dan website), Public Relations (press release, press demonstration, press conference, familiarization visits, exhibitions, participation on fairs, anniversary, travel documentary film for cinema or tv). Selain itu akan dilihat pula kegiatan perencanaan kegiatan promosi dan riset pemasaran pariwisata.

Tata ruang melingkupi tata letak lokasi atraksi, fasilitas, dan faktor pendukung lainnya. Di dalamnya dapat dinilai kebijakan tata ruang, kedisiplinan, dan toleransi terhadap penyimpangan terhadap perencanaan tata ruang yang telah ditetapkan. Selain itu akan dinilai pula nilai subyektivitas pengunjung terhadap keindahan tata ruang yang ada d daerah setempat.

Kegiatan konservasi terdari dari perlakukan pihak pengelola dalam melakukan konservasi norma agama, sosial budaya, konservasi alam, dan memperhatikan daya dukung lingkungan. Aspek yang dinilai adalah kegiatan adaptasi, penguatan, dan toleransi terhadap pelanggaran prinsip konservasi dan daya dukung lingkungan.

Keterlibatan masyarakat akan diukur dari kebijakan pengelola dalam melibatkan partisipasi masyarakat dalam kegiatan usaha wisata seperti memperkaya souvenir dari hasil produk masyarakat sekitar, kepemilikan investasi dalam unsur hospitality, amenitas, dan moda transpotasi, sikap dan perilaku 
masyarakat, kediplinan dalam pemanfaatan ruang dalam lingkngan kawasan wisata, dan lain-lain.

\section{Kesimpulan Dan Saran}

Pengembangan sertifikasi kawasan wisata adalah sesuatu yang rasional dan dapat dilaksanakan. Ada sejumlah alasan perlunya sertifikasi yaitu pertama mendesaknya usaha perlindungan kelestarian lingkungan hidup dan sosial budaya dari dampak pengembangan kawasan wisata. Kedua, banyak kasus produksi barang dalam negeri yang terjegal oleh sistem sertifkasi lembaga luar negeri ketika dilempar ke pasaran dunia. Untuk melindungi kawasan wisata tanah air dari sertifikasi yang tidak adil dari lembaga asing, maka perlu dibuat sistem sertifikasi dari dalam negeri yang lebih bersifat melindungi.

Selain memiliki keunggulan, terdapat pula sejumlah kelemahan sistem yaitu bahwa ruang lingkup sertifikasi sangat luas sehingga tidak dapat menilai aspek-aspek yang lebih spesifik. Sertifikasi yang ideal sebenarnya cukup dalam satu bidang saja yaitu dalam bidang fasilitas, produk wisata, mutu pelayanan, dan atau manajemen pemasaran. Berdasarkan hasil studi literatur nampaknya pengembangan sistem sertifikasi kawasan wisata perlu dimantapkan melalui suatu uji coba yang lebih luas dan berdasarkan riset.

\section{DAFTAR PUSTAKA}

Bonafice and Cooper, 1991, The Geography of Travel and Tourism, London : Heineman.

Burn, M Peter dan Andrew Holden, 1995, Tourism, a New Perspective, UK : Prentice Hall.

Cooper, Criss; John Fletcher; David Gilbert and Stephen Wanhill, 1993, Tourism, Principles and Practice, London : Pitman Publishing.

Darsiharjo, dkk. 2007. Pengembangan Kriteria Standar Untuk Sertifikasi Kawasan Wisata Dengan Menggunakan Sistem Teknologi Informasi Dalam Era Otonomi Daerah. Penelitian Hibah Bersaing. DIKTI Jakarta.

Diroktorat Jenderal Pariwisata Jawa Barat, 1996, Pembangunan dan prospek Pembangunan Pariwisata Jawa Barat.

Fandeli, C. 2000. Pengusahaan Ekowisata. Fakultas Kehutanan Universitas Gadjah Mada. Yogyakarta.

Fandeli, C. 2002. Perencanaan Kepariwisataan Alam. Fakultas Kehutanan Universitas Gadjah Mada. Yogyakarta.

Fredgen, 1991, Dimention of Tourism, Amerika : Edication Institute.

Gee, 1984, Travel Industry, Connecticut : Black Wall.

Geofree, 1989, Tourism Economic, Physical and Social Impacts, New York : Longman.

Gold, Seymour, 1980, Recreation Planning and Design, New York : Mc Grew Hill BookCompany.

Hall dan Page,1999, The Geography of Tourism and Recreation, Environment, Place and Space, New York : Routledge.

Hardjowigeno, dkk. 1994. Evaluasi Lahan Untuk Pariwisata. Centre For Soil And Agroclimate Research, Bogor. 
Inskeep, 1991, Tourism, Planning, an Integrated Sustainable Development Approach, New York : Van Norstand Reinhold.

Intosh, Mc. Robert W dan Charles Geoldner, 1977, Tourism Principles, Practices Philosophies, Ohio : Gris Publishing.

Marpaung, H. Dan Bahar, H. 2002. Pengantar Pariwisata. Bandung. Penerbit Alfabeta.

Maryani, 1997, "Kiprah geografi dalam kepariwisataan". dalam Geosfer, Majalah Geografi IKIP Bandung.

Mathieson, and Geoffrey Wall, 1982, Tourism ; Economic, Phisical and Social Impacts, Longman : Harlow.

Murphy, 1985, Tourist a Community Approach, London : Meutheen.

Pearce, 1981, The Social Psychology of Tourist Behaviour, Oxford : Pergamon.

Pearce, 1989, Tourism Development, UK : Longman.

Pearce, 1995, Tourism Today a Geographycal Analysis, England : Longman.

Pendit, S. 1987. Ilmu Kepariwisataan: Suatu Pengantar Perdana. Pradnya Paramita. Jakarta.

Robinson, 1976, Geography of Tourism, London : Mac Donald.

Situs www.visittheoregoncoast.com. Outdoor Recreation. 30 Mei 2006.

Situs www.grandbahamanaturetours.com. Outdoor Recreation. 6 April 2006.

Smith, Stephen, 1989, Tourism Analysis a Handbook, New York : John Wiley and Sons.

Yoeti, A. 1997. Perencanaan dan Pengembangan Pariwisata. Pradnya Paramita. Jakarta. 